\title{
Value Added Products from Ber
}

\author{
Nidhi Dalal ${ }^{1}$, Neeraj ${ }^{2}$ and Vinita Bisht ${ }^{3 *}$ \\ ${ }^{1}$ CCS HAU, Hisar, Haryana, India \\ ${ }^{2}$ Jharkhand Rai University, Ranchi, India \\ ${ }^{3}$ Banda University of Agriculture \& Technology, Banda (U.P), India \\ *Corresponding author
}

A B S T R A C T

\begin{tabular}{|l|}
\hline K e y w o r d s \\
$\begin{array}{l}\text { Ber, Value added } \\
\text { products, Medicinal } \\
\text { value }\end{array}$ \\
\hline Article Info \\
\hline $\begin{array}{l}\text { Accepted: } \\
12 \text { December } 2018 \\
\text { Available Online: } \\
\text { 10 January } 2019\end{array}$ \\
\hline
\end{tabular}

\section{Introduction}

India is one of the few countries in the world where climatic variations allow production of different types of fruits and vegetables. The Indian arid zone covers around $12 \%$ of country's geographical area occupying 31.8 million ha of land. It covers parts of Andhra Pradesh, Gujarat, Haryana, Karnataka, Maharashtra, Punjab and Rajasthan states of India. With the increasing biotic pressure, most of the arid and semi-arid regions are confronted with the challenges of producing more per unit land with uncertain and dwindling supplies of water. Ber (Zizyphus mauritiana Lamk) is one such fruit that has
Ber (Zizyphus mauritiana Lamk) belongs to the Rhamnaceae family and is also called as jujube. It grows in arid and semi-arid regions of India and there are 125 varieties of ber in India. The cultivars Umran, Kathapal and Gola are the most promising varieties of ber in North India. Although known for its rich taste and high nutritional value, ber is an under utilised fruit and is available only for a short period of time. Value addition is a great way to increase the shelf life of the product along with adding economic value to it. It is an effective to use the surplus and meet the demands during scarcity. In the following review different processing aspects of ber are discussed and ways in which we can utilise this under-appreciated fruit to its full potential. Products like jam, candy, preserve, powder, murabba, beverages, wine, pickle etc. can be prepared from ber. Apart from this ber is also used in traditional medicinal systems in India and other countries. 
available in India. A few of these varieties are known for taste, size, amount of pulp and higher yields. The cultivars Umran, Kathapal and Gola are the most promising varieties of ber in North India (Azam-Ali et al., 2001).

Most fruits are seasonal and highly perishable and it is estimated that the total loss of fruits in India, for want of adequate post harvest care, transportation and storage is around 2030 per cent (Madan and Ullasa, 1993).

Desiccation damage in ber is caused by high cuticular transpiration, which is reported to be associated with high levels of fatty acids and low levels of aldehydes and alcohols in the wax cuticle rather than with the thickness of the cuticle and wax itself (Rao et al., 1981). $B e r$ is a seasonal fruit and can be made available throughout the year with different food products with longer shelf life.

\section{Value addition}

Selling the products at the lowest market value just to survive economically is not sustainable. It can lead to stress on the land as well as on the farmer. "Value-added" is simply anything we can do to raise the value of our product in the market. Value-added practices are key to future of sustainable farming, because they enable growers to advance economically without having to "pump-up" the production of raw materials from the land. USDA defines value addition as:

A change in the physical state or form of the product (such as milling wheat into flour or making strawberries into jam).

The production of a product in a manner that enhances its value, as demonstrated through a business plan (such as organically produced products).
The physical segregation of an agricultural commodity or product in a manner that results in the enhancement of the value of that commodity or product (such as an identity preserved marketing system).

As a result of the change in physical state or the manner in which the agricultural commodity or product is produced and segregated, the customer base for the commodity or product is expanded and a greater portion of revenue derived from the marketing, processing or physical segregation is made available to the producer of the commodity or product (http://www.agmrc. org/business-development/getting-prepared/ valueadded-agriculture/articles/usda-valueadded-ag-definition/)

Advantages of value addition are:

Improve the profitability of farmers

Reduces the glut in market during peak season of produce

Produce that cannot be stored can be converted into value added product increasing the profit

Empower the farmers and other weaker sections of society especially women through gainful employment opportunities and revitalize rural communities

Provide better quality, safe and branded foods to the consumers

Odd looking fruits and vegetables (too big to too small in size, overripe, partially infected, etc) can be easily converted into value added products

Emphasize primary and secondary processing Reduce post harvest losses

Reduction of import and meeting export demands

Way of increased foreign exchange

Encourage growth of subsidiary industries

Reduce the economic risk of marketing Increase opportunities for smaller farms and companies through the development of markets 
Diversify the economic base of rural communities

Overall, increase farmers' financial stability

It is a paradox in India that even though we are the $2^{\text {nd }}$ largest producers of fruits and vegetables in the world but our shard in world food trade is a merely $1.6 \%$. The post harvest losses in India are estimated to be 3-16\% which amount to a whopping $\square$ 92,651crores. Only $2 \%$ of fruits and vegetables are India is processed even though we have a large population of middle class with apt purchasing power and a young generation that is open to new food choices (http://mofpi.nic.in/e-book). The next logical step after self sufficiency in food production after green revolution is to increase the quality of food.

In times when time is of essence, food that can last longer with high nutritional value is preferred by the customer. That is where preservation of food through value addition comes in. People don't want to preserve food at home and want food that can easily be consumed and are healthy at the same time. Value addition is the need of the hour due changing market trends and changing lifestyle.

Moreover, some of these values added or preserved products such as canned mangoes, fruit juices, salted cashews, dehydrated foods, and frozen fruits are gaining popularity in the foreign market and are good foreign exchange earners. Value addition can be achieved by processing the fruits into various forms. These forms are liquid and solid, semi-solid and solids forms. Liquid forms include unfermented beverages (pure fruit juice, fruit juice beverage, squash, cordial, crush, fruit juice concentrate, RTS, nectar, crush, syrup, sarbat, barley water, carbonated beverage) and fermented beverages (alcohol, vinegar), puree, sauce, ketchup etc. Semi-solid forms include pulp, jam, jelly, marmalade and chutney. Solid forms include canning, drying, preserves, candy and pickling (Devi et al., 2015).

\section{Nutritional value of ber fruit}

Indian ber is mainly valued for its sweet, sour and delicious fruits. The ripe fruit is of great medicinal value and supports blood pressure lowering, aids stomach and diarrhoea infection, cures sore throat and regulates excess bile secretion. The pulp of the ber fruits is of most importance in relation to nutrition.

The ber fruit pulp has high sugar content (sucrose, glucose fructose and starch); it is, therefore, high in carbohydrates, which provide energy. The fruits also contain protein with many essential amino acids like asparginine, arginine, glutamic acid, aspartic acid, glycine, serine and threonine (Bal, 1981). It contains good amount of vitamins A, $\mathrm{B}$ complex and $\mathrm{C}$ in comparison to other fruits (Anon 1976). Ber fruits are also higher in calorific value and ascorbic acid as compared to apple and orange. It is also rich in calcium, phosphorus and protein (Jawanda and Bal 1978).

Caffeic acid, p-hydroxybenzoic acid, ferulic acid and p-coumaric acid are predominant phenolics reported in ber (Tanmay et al., 2011; Ayaz et al., 2012) which account for its significant antioxidant activity, reducing power activity and scavenging of free radical activity (Krishna and Parashar, 2012). Indian Ber contain good source of ascorbic acid and total phenolics ranging from 19.54 to 99.49 $\mathrm{mg} / 100 \mathrm{~g}$ and 172 to $328.6 \mathrm{mg} \mathrm{GAE} / 100 \mathrm{~g}$ respectively (Koley et al., 2011) and average antioxidant activities were 1.6-6.33 and 1.22 $-5.49 \mu \mathrm{mol} \mathrm{TE} / \mathrm{g}$ as the CUPRAC and FRAP assays, respectively (Krishna and Parashar, 2012).

Different value-added products that can be 
prepared with Ber are:

Ber candy

Ber jam

Ber preserve

Dehydrated and sundried ber

Ber beverages

Ber pickle

\section{Ber candy}

Singh et al., (1944) standardized the candying of ber. The punctured fruits were cured in brine for 6-7 days, washed free of salts and boiled for 2-5 minutes to soften them. Sugar syrup of $30^{\circ} \mathrm{B}$ having $0.1 \%$ citric acid was then poured on the fruits which were kept submerged for 24 hours. The density of the syrup was raised gradually to $75^{\circ} \mathrm{B}$ in a course of 10-12 days. The syrup was drained to and fruits were dried in shade to make ber candy. Singh (1975) did not recommend curing in brine but the latter process was same.

Kaikadi et al., (2006) prepared ber candy from 'Umran' cultivar by slow syruping method. For this, mature ber fruits after pricking, destined and blanched in hot water for 5minutes. Sulphur fumigation was done @ $2 \mathrm{~g} / \mathrm{kg}$ for 2 hours. Then sugar syrup of $40^{\circ}$ Brix was prepared and fruit was added to it. At this stage, 1 per cent citric acid was added and stored for 24 hours. Next day the strength was increased by $10^{\circ}$ Brix with addition of 1 per centcitric acid. The process was repeated till $70^{\circ}$ Brix was reached with addition of 1 per centcitric acid. The fruits were stored for 7-8 days. The fruits were washed quickly and dried in shade until the moisture content was below 18 per cent. The moisture, reducing sugar, total sugar and ascorbic acid content was $19.8 \%, 29.5 \%, 77.0 \%$ and $24.8 \mathrm{mg} / 100 \mathrm{~g}$, respectively. In all cases, storage container was not found to have significant influence on any chemical component of ber candy.
Kumar et al., (2007) prepared RTS using ber powder at different concentrations of 5, 10 and $15 \%$ and recorded ascorbic acid from 2.02 to $6.03 \%$, reducing sugars from 3.87 to $4.36 \%$ and non-reducing sugars from 6.28 to $6.77 \%$. The total sugars content was $10.64 \%$. All the RTS prepared could be stored safely up 00000.to 3months and were liked moderately during storage. Take and Bhotmage (2012) prepared candy from ber. Cleaned and matured pricked ber fruits were subjected to sodium metabisulphite and blanching treatments. The latter process remained more or less the same. Results showed that candy treated with sodium metabisulphite scored higher than that of blanched with hot water.

\section{Ber jam}

Jams are most popular fruit preserves (or) conserve is the product prepared from whole fruit, pieces of fruit, fruit pulp or fruit puree and with or without fruit juice or concentrated. Fruit juice as optimal ingredients and mixed with carbohydrate sweetener, with (or) without water and processed to a suitable consistency" (Ranganna, 1977).

Dubey et al., (2014) evaluated the quality of ber jam during storage period. The physicochemical attributes of ber jam results showed that there were slight differences in the various constituents of ber jam made on 0.2 and $0.3 \%$ citric acid. The ber jams contained moisture $29.16 \%$ and $29.80 \%, \mathrm{pH}$ 3.69 and 3.90 , TSS $70^{\circ} \mathrm{B}$, acidity $0.5 \%$ and $0.57 \%$, ascorbic acid 27.03 and 27.98 $\mathrm{mg} / 100 \mathrm{~g}$, reducing sugars 19.23 and $19.10 \%$, non reducing sugars 39.78 and $40.62 \%$, calcium 9.01 to $9.95 \mathrm{mg} / 100 \mathrm{~g}$ and phosphorus 4.02 and $4.33 \mathrm{mg} / 100 \mathrm{~g}$ product, respectively. A gradual decrease in ascorbic acid content and calcium content was reported in the ber 
jam. It was concluded that the ber jam having $0.3 \%$ citric acid could be well stored upto 60 days without deterioration of the product quality.

Sucharitha et al., (2012) evaluated the quality of ber and pineapple jam during storage period for their significant nutritional and medicinal value. It was found that the final product which consists of Ber pulp (60\% $\mathrm{w} / \mathrm{w})$, pineapple pulp (40\% w/w), and sugar as its major ingredients, the energy was 493.4 Kcal, 121.5 of carbohydrates and 1.056 of proteins and $0.31 \mathrm{~g}$ of fat for $100 \mathrm{~g}$. The carotene and Vitamin $\mathrm{C}$ content of the Jam were $30.75 \mu \mathrm{g}, 95.4 \mathrm{mg}$. The calcium and iron content in the final product was $30.1 \mathrm{mg}$ and $2.355 \mathrm{mg}$ respectively. Other micronutrients magnesium and Potassium content was found to be $35 \mathrm{mg}$ and $27.38 \mathrm{mg}$ respectively for $100 \mathrm{~g}$. Goyal et al., (2008) studied the vitamin $\mathrm{C}$ content and overall acceptability of ber jam. It was observed that the content in the raw ber was found to be $84 \mathrm{mg} / 100 \mathrm{~g}$ whereas it was recorded as $27.32 \mathrm{mg} / 100 \mathrm{~g}$ in ber jam.

\section{Ber preserve}

Mature fruits can be used to make a preserve, known locally in India as murabba. Fruits of the cultivars Umran, Banarsi, Karaka and Kaithli are the best for the preparation of preserve (Pareek, 2001).The best preserve is made from fully mature fruits that are at the hard stage. Ripe fruits are not suitable since the structure will be too soft.

Khurdiya and Singh (1975) standardized the process of ber murraba. Fully mature ber fruits wer blanched in boiling water for 6 minutes followed by rinsing in cold water. The fruits were then peeled and pricked. Destoning with cork borer could also be done, if desired. The prepared fruit was kept overnight in 20 to 30 per cent sugar syrup containing 0.5 per cent citric acid. Next day more sugar was added to the syrup at the rate of $250 \mathrm{~g}$ per ' $\mathrm{kg}$ of prepared fruit and boiled for few minutes, the process being repeated on fourth and sixth day. After one week, the syrup was concentrated to 70 per cent. Murraba thus prepared could be stored easily for a year.

Goyal et al., (2008) studied the vitamin C content and overall acceptability of ber preserve. It was observed that the content in the raw ber was found to be $84 \mathrm{mg} / 100 \mathrm{~g}$ whereas it was recorded as $50.83 \mathrm{mg} / 100 \mathrm{~g}$ in ber preserve.

\section{Dehydrated and sun-dried ber}

When $85-88 \%$ moisture is evaporated artificially from fruits or vegetable slices, either by keeping them in the sun or under controlled temperature and humidity conditions inside an oven, this is known as drying. Drying done by sun exposure is sun drying; when done under controlled temperature and humidity in a closed chamber (dehydrator), this is known as dehydration. The main idea behind dehydration or drying is to reduce the moisture level to a point where microorganisms cannot grow.

Ber fruit has high nutritive value, especially carbohydrates and vitamin $\mathrm{C}$ with good amounts of minerals like phosphorus, calcium and iron and high sugar to acid ratio at ripe stage. These attributes are ideal for a fruit to be dehydrated. Kumar and Nath (2002) studied dehydration of ber fruits and reported that there was non-significant difference in pretreatment and osmo-drying on fat content of ber fruits. The ash content of pre-treated air dried fruits was highest ( 0.63 per cent) as compared to untreated osmo dried fruits $(0.51$ per cent) and pre-treated osmo air dried (0.43 per cent).

For making a superior dried product with ber, the fruits should be blanched for 5 minutes in boiling water before dehydration (Pareek, 
1983). Khurdiya and Singh (1975) have recommended exposure of the blanched fruit to sulphur dioxide fumes in a sulphur box by burning sulphur powder at the rate of 3.5 to $10 \mathrm{~g}$ per $\mathrm{kg}$ of fruit for 3 hours. They are dried to $15-20 \%$ moisture. The dehydrated fruit can be eaten as such or can be reconstituted in $10 \%$ sugar solution to be consumed as liquid beverage. Powder from ber fruit can be rehydrated into RTS beverages (Kadam, 2001).

Khurdiya (1980b) studied the effect of dehydration on different varieties of ber. 'Umran, 'Bagwari' and 'Chhuara' varieties were good for drying. Fruits having golden yellow to reddish brown colour were found superior for drying. Sulphuring at the rate of $150 \mathrm{~g} \backslash 8 \mathrm{~kg}$ of fruits was considered optimum. The rate of browning increased during storage for 6 months at room temperature $\left(21-38^{\circ} \mathrm{C}\right)$. All the varieties except 'Ilaichi' were found acceptable organoleptically. Chawan et al., (1993) studied processing of ber and papaya and indicated that the overall organoleptic score of bertuty-fruity was better than that of papaya tuty-fruity.

Kumar (2006) prepared ber powder by dehydrating ripe ber fruits using sun drying and oven drying techniques with different pre-treatments and reported that the powder contained total sugars $57.38 \%$, reducing sugars $36.98 \%$, non-reducing sugars $20.40 \%$ and ascorbic acid $35.17 \%$. Nutritional composition of Ber candy in terms of moisture content, TSS, ascorbic acid, acidity, total sugars and reducing sugar was found to be as $10.08 \%, 48{ }^{\circ} \mathrm{B}, 95.97 \mathrm{mg} / 100 \mathrm{gm}, 0.225$ $\%, 21.65 \%$ and $9.67 \%$ respectively (http://vikaspedia.in/agriculture/post-harvesttechnologies/technologies-for-agri-horti-crops /preparation-of-ber-candy). Kumar and Nath (2002) developed the conditions for preparation for chuhura like products from ber by osmo-air drying process. 'Umaran', a commercial variety of ber, was pre-treated by dipping in boiling $1 \% \mathrm{NaOH}$ solution for 1 min followed by rinsing in water and 5\% citric acid and dipping in 4000 ppm KMS solution for 12 hours. Pre-treated bets when osmotically dried using $30-60^{\circ}$ Brix sugar syrup reduced moisture content from 84.4 to $48.4 \%$. Further drying at $52 \pm 2^{\circ} \mathrm{C}$ for $29 \mathrm{~h}$ in a cross flow cabinet air drier gave yellow, sweet, chewable and appealing product with $12.7 \%$ moisture. Its water activity was 0.43 and the product stored well under relative humidity of 40.0 - 56.3\%. Gupta and Kaul (2011) prepared Chuhura-like product from ber by osmo-air drying process Before making chuhara, the ber (Zizyphus mauritiana Lamk.) fruits were subjected to different pretreatments, viz., lye peeling $(5 \% \mathrm{NaOH}$ for 5 min.), citric acid treatment (5\% for $5 \mathrm{~min}$.) and KMS treatment (@ 4000 ppm for 12 h). Pretreated ber were dipped in different sugar concentrations of $40,50,60$ and $70^{\circ}$ Brix at 24, 48 and 72 hours. The treated fruits were then dried at $52^{\circ} \mathrm{C}$ for $6 \mathrm{~h}$ in a dehydrator till a chewable and appealing product was developed. Sensory evaluation revealed that $70^{\circ}$ Brix at 72 hours gave best chuhara-like product from ber through osmo-air drying process and could be an acceptable product.

Bajaj (2013) prepared value added products with ber powder from Gola, Umaran and Kaithali varieties. The acidity, total soluble sugars/acid ratio and browning of powders ranged from 2.09 to $2.19 \%, 8.82$ to 9.66 and 0.08 to 0.09 , respectively. The moisture, crude protein, crude fat, crude fiber and ash content of ber powders varied from 5.21 to $5.68,6.92$ to $7.83,0.99$ to $1.07,3.52$ to 3.91 and 4.27 to $4.49 \%$, respectively. The total soluble sugars, reducing sugars and non reducing sugars content of powders ranged from 19.08 to $20.17,3.61$ to 3.98 and 15.47 to $16.19 \%$, respectively. The calcium, iron, magnesium and zinc content of powders varied from 148.56 to $153.63,17.87$ to 18.65 , 
84.43 to 90.33 and 0.91 to $0.98 \mathrm{mg} / 100 \mathrm{~g}$, respectively. The ascorbic acid and $\beta$-carotene content of powders varied from 46.77 to 48.23 and 2.38 to $2.94 \mathrm{mg} / 100 \mathrm{~g}$, respectively. The in-vitro protein and starch digestibility of powders ranged from 76.53 to 78.53 per cent and 40.13 to $41.80 \mathrm{mg}$ maltose released/ $\mathrm{g}$ powder, respectively. All the powders were studied for shelf-life for two months and were found to be organoleptically acceptable during storage. Powder of Umran variety of ber was used for the development of valueadded products due to superior qualities. The products were developed under four categories which included traditional (custard and kheer), baked (biscuits and cake), extruded (pasta and noodles) and unfermented beverage (RTS beverage) by using different concentrations of ber powder. All the baked products had good acceptability scores. The traditional products and extruded products were best acceptable up to $30 \%$ supplementation while and unfermented beverage up to $20 \%$ supplementation with ber powder. Results of nutritional analysis indicated that all the nutrients content increased as the supplementation level of powder increased except the protein content of baked and extruded products. All the stored products were organoleptically acceptable except RTS beverage prepared using 40\%berpowder. Biscuits prepared with 10, 20 and $30 \%$ and pasta, noodles and RTS beverage prepared with 10 and $20 \%$ berpowder were best acceptable among all during storage.

\section{Ber beverages}

All drinks, unfermented or fermented, sweetened or unsweetened, are designated as beverages. It includes squash, nectar, crush, wine, RTS etc.

Fruit based beverages are becoming increasingly popular in the market with the growing consciousness of people in the nutritive value of fruits (Srivastava and Kumar, 2002).Investigations on preparation of various products from ber fruits (Zizyphus mauritiana) were conducted by $\mathrm{Bal}$ and Ranadhava (2005). They concluded that the juicy varieties such as Sanour-2, ZG-2, and Kaithli can be converted into pulp to serve as base material for squash.

Khurdiya (1980a) studied on a Ready to Serve beverage containing $33.3 \%$ juice prepared from dried ber fruit after cooking and extracting the juice in a basket press. The juice had a $\mathrm{pH}$ of 3.75 and $19.6^{\circ}$ Brix with $0.56 \%$ acidity. The juice extracted from ber fruits and processed at $80^{\circ} \mathrm{C}$ for $10 \mathrm{~min}$. stored well for 9 months at room temperature $\left(20-38^{\circ} \mathrm{C}\right)$. The beverage was organoleptically acceptable on evaluation. Goyal et al., (2008) studied the vitamin $\mathrm{C}$ content and overall acceptability of ber squash. It was observed that the content in the raw ber was found to be $84 \mathrm{mg} / 100 \mathrm{~g}$ whereas it was recorded as $39.90 \mathrm{mg} / 100 \mathrm{~g}$ in ber squash.

Kavitha and Kuna (2012) studied the effect of processing on antioxidant properties of ber. Ber fruit was blanched and RTS was prepared to evaluate the antioxidant activity by different methods, viz. DPPH radical activity, reducing power assay, superoxide anion radical activity, TBARS, total phenolic content and total flavonoid content. Blanching of ber fruits enhanced the total flavonoid content and super oxide anion radical activity but, at the same time, it reduce the scavenging radical activity, reducing power activity and total phenolic content compared to fresh fruit. Secondary processing of ber fruits slightly slowed down the scavenging radical activity, reducing power activity, total flavonoid content and total phenolic content but raised the super oxide anion radical activity in RTS Ber beverage. TBARS activity of fruit increased 29\% on blanching and 52\% in RTS ber beverage. Younis et al., (2014) prepared wine from ripe guava and ber fruit. Juices of 
both the fruit were used to prepare wine. Further the juices were adjusted with different TSS as $10,15,20,25$ and $30 \%$ by adding cane sugar in powder form and samples were fermented at $30{ }^{\circ} \mathrm{C}$. It was seen that juice having TSS $15 \%$ showed higher ethanol production as compare to juices having different TSS in both guava and ber fruit juices. 15\% TSS juices were further adjusted with different $\mathrm{pH}$ by using diluted $\mathrm{NaOH}$ and $\mathrm{H}_{2} \mathrm{SO}_{4}$ and kept for fermentation at $30^{\circ} \mathrm{C}$. It was shown that ber and guava juices having $\mathrm{pH} 4$ yield higher alcohol as compare to samples having different $\mathrm{pH}$. It was also seen that there was very less production of alcohol percentage in case of ber juices.

Jakhar and Pathak (2012) prepared RTS by blending ber and jamun pulp. The different blending ratios of ber and jamun pulp were 75:25, 50:50, and 25:75, respectively. RTS using 100 per cent ber pulp and 100 per cent jamun pulp were also developed. They found that RTS prepared using $25 \%$ ber pulp and $75 \%$ jamun pulp scored highest mean scores followed by RTS prepared using ber and jamun pulp in the ratio of 50:50 and RTS prepared using 100 per cent jamun pulp. All the prepared RTS blends were organoleptically acceptable. There was a gradual decrease in organoleptic score of the blended RTS beverage during the storage period at room temperature. The RTS was found acceptable up to five months of storage.

\section{Ber pickle}

Pickling is the process of preserving or expanding the life span of food by either anaerobic fermentation in brine or immersion in vinegar. Ber fruit are highly mucilageous, have low acidity and are not ideally suitable for pickling. Shobha and Bharati (2007) standardized the procedure for pickling of ber as a form of value addition. The acidulants used in pickle preparation were lemon and salt and three variants were prepared with varying concentrations of salt, lemon and spices. When freshly prepared, vinegar based pickle scored maximum for texture (2.73) and taste (2.86) compared to lemon based pickle. Lemon treated pickle was better accepted up to three months of storage compared to vinegar based pickle, both at the laboratory and consumer level. With the advancement of storage the loads of bacteria increased in pickle with lemon as acidifying agent. There were no fungal colonies in the vinegar added pickle throughout the storage period.

\section{Medicinal uses}

Ber contains numerous ethnopharmaceutical compounds. These include ascorbic acid, thiamine, riboflavin, bioflavonoids, alkaloids, pectin A, glycosides (spinosins, saponins, triterpenoic acids, betulinic acid and oleanolic acid) and lipids (Azam-Ali et al., 2001). Ber also have neurological properties (hypnoticsedative and anxiolytic effect and cognitive activities), hypotensive and antinephritic effect, cardiovascular activity, immunostimulant effects, antifungal, antidiabetic, antiallergic, antiulcer, antiinflammatory, antispastic, antioxidants and antibacterial activities (Azam-Ali et al., 2001).

Uses of ber not only involve its use as food ingredient, but it also has diverse uses in traditional medicine. This knowledge is passes down from generation to generation and may or may not be based on knowledge of the constituents of the ber fruit. The traditional medicinal uses of ber are culturally relevant in areas where the production of ber is abundant. Those that are prevalent and used consistently are summarised below. According to Ayurveda, the fruit of $Z$. nummularia is cooling, digestible, tonic, aphrodisiac, laxative and removes biliousness, burning sensations, thirst, vomiting and is 
also good in treating tuberculosis and blood diseases. The seeds cure eye diseases and are also useful in leucorrhoea (Oudhia, 2001-3).

The natives of Chhattisgarh, India use fresh $Z$. nummularia fruit to treat common fevers. In cases of vomiting, the seeds with bar sprouts (Ficus benghalensis) and sugar are used. According to the Unani system of medicine, the fruits are sweet and sour, and can cause diarrhoea in large doses. The seeds are astringent, are a tonic to the heart and brain and relieve thirst. Powder made by crushing the dried seeds of $Z$. nummularia is said to improve digestion and acts as carminative is consumed in appropriate amounts (Oudhia, 2001-3).

Chinese herbology describes $Z$. spinosa, the wild spiny $Z$. jujuba, as sedative and hypnotic. Traditionally it is used to nourish the heart, calm the nerves and is useful for insomnia and dream disturbed sleep (Zhu, 1998). It is a common belief in China that if the wild Z. jujube (suan-tsao) is taken on a daily basis, it will improve skin colour and tone, both signs of physical wellbeing. Its domestic equivalent (pei-tsao), is said to reduce pain, distress and sleeplessness.

They are used to treat rheumatic symptoms and are said to rejuvenate the body, whether it is suffering from stress or age. Fresh $Z$. Jujube is also used to increase strength of the seriously ill and reverse the process of disease.

In modern Chinese medicine, Z. jujube is used to tone the spleen and stomach, to treat shortness of breath and severe emotional upset and debility due to nerves, and to mask the flavours of unpleasant-tasting herbs (Plant Botanic). The Arabs use the fruits of $Z$. jujuba, Z. mauritiana and Z. spina-christi to ensure health. The leaves of the plant kill diarrhoea-causing parasites and worms in the intestinal tract. The fruits are said to cure coughs, resolve any other lung complaints, soothe the internal organs and reduce water retention. In Saudi Arabia, fruits of Z. spinachristi when in sufficient strength act as a laxative (Azam-Ali et al., 2001). In Haiti, fruits, leaves and roots of introduced $Z$. jujube are boiled to make a decoction and this is used as tea for an antidote to poison (Plant Botanic).

\section{Other uses}

In Zambezi valley in Zimbabwe, the dry powder is used in baking and to prepare jam (Maposa and Chisuro, 1998) and a traditional loaf (Kadzere, 1998), and kachaso, a crude spirit (Arndt, 2001). An alcoholic drink is also made in Malawi (FACT Net).In West Africa wild $Z$. mauritiana fruits are used to produce an alcoholic drink (Hutchinson and Dalziel, 1958). Cakes are made out of dried and fermented pulp in western Sudan (Dalziel, 1937), and in Zambia (Kalikiti, 1998).

The Touareg nomads in Mali make flatbread from dry fruit pulp (Chevalier, 1947) using wild species. In Niger ber fruits are dried and pounded into flour as a famine food (Williams, 1998). In Namibia, wild $Z$. mucronata Willd, is used for making a hot liquor (Hailwa, 1998).

In Venezuela a liqueur is made from the fruits and sold as 'Crema de ponsigue' (Morton, 1987). Of the 7 species of Ziziphus indigenous to the New World, Z. mistol Grisels was found in the Andes of Argentina and Paraguay to be used for making 'mistol jam'.

In the Indian state of Chattisgarh, $Z$. nummularia fruits are sun dried and crushed to make a power called 'Birchun' or 'Borkut' (Oudhia, 2001-03).

Future prospects 
$B e r$, as an indigenous fruit also has the potential of a huge market in India. The potential of market of ber in India is untapped since there are no major products of ber. Another circumstance in favour of ber is the production requirements. As mentioned earlier, ber doesn't require extensive water to grow and thus can be grown over a large part of India. It can easily replace water extensive crops and thus bring down the cost of farming and save water, which is the need of the hour. Fruits like anola, mango, apple etc. have multitude of products available due to their easy availability and market demand. Also, since people are evidently accustomed to the taste of ber, it can easily create a niche for itself in the Indian market. The availability of the fruit only for a few months in a year can further widen the demand. The same strategy, if applied to ber for production of variety of products with a decent shelf-life can lead to market gains which in turn would lead to more demand and provide prosperity to the farmers. The availability of advanced methods of storage like cold chain stores can make sure that the fruit is available throughout the year for processing.

More studies can be executed on preparation of value added products with ber. Addition of other fruits and flavouring ingredients like spices can further broaden the prospects of usage of ber. Advanced methods of preservation and processing can be used to obtain a product of higher nutritional value and more retention of natural characteristics of the original fruit. Possibility of preparation of other products like squashes, concentrates, marmalades, butter, jellies etc. can be explored and exploited. Not only will such products will be a treat to the consumer, but they would also have a higher nutritional value that will add to their aesthetic appeal.

It is concluded that in the underutilized status of Zizyphus mauritiana Lamk can be changed by different value additions to it. In India the cultivated horticultural varieties grown are Gola, Umran, BanarasiKarka, Mundia, Kaithli, Umran, Mehrun, Parbani, Elaichi and Sanam. The seasonal and perishable nature of Ber leads to the various value added products like Ber candy, Ber jam, Ber preserve, dehydrated and sundried ber, Ber beverages, Ber pickle are used for keeping best quality of this fruit. The medicinal properties like neurological properties, antinephritic effect, cardio-vascular activity, immuno-stimulant effects, antifungal, antidiabetic, anti-allergic, antiulcer, antiinflammatory, anti-spastic, anti-oxidants and anti-bacterial activities have been used since ancient times for curing various illnesses.

\section{References}

Anon (1976) In: Karnataka Statistics, Department of Horticulture Govt of India 1

$\begin{array}{llll}\text { Arndt } & \text { S. } & \text { K. }\end{array}$ http://chemsrv0.pph.univie.ac.at/ska/zi plant.htm

Ayaz, A.M., Najma, M., Devan, L.L, Amanat, A.P and Muhammad, I.B. (2012). Phenolic Compounds and Seed Oil Composition of Ziziphus mauritiana L. Fruit. Polish Journal of Food Nutrition Science, 62 (1): 15 -21.

Azam-Ali, S., Bonkoungou, E., Bowe, C., DeKock, C., Godara, A and Williams, J.T. 2001. Fruits for the future (revised edition) Ber and other jujubes. International Centre for Underutilised Crops, University of Southampton, Southampton, SO17 1BJ, UK.

Bajaj, M. (2013). Nutritional evaluation and utilization of ber (Ziziphus mauritiana Lamk.) powder for the development of value added products (Doctoral dissertation, CCS Haryana 
Agricultural University, Hisar, Haryana.

Bal J. S. (1981). A note on sugars and amino acids in ripe ber. Progressive Horticulture, 13 (3/4): 41-42.

Bal, J. S., Ranadhava, J. S. (2005). Studies on the preparation of various products from the fruits. International Journal of Agricultural Sciences, 1(1): 56-57

Bolada, S., Sehrawat, S. K., Yadav, B. S., Ahlawat, V. P. and Sulthan, S. (2012). Present status of ber production and future thrusts in India- a review. Agriculture Reviews, 33(3): 256 - 264.

Chawan, U. D., Adsule, R. N. and Kadam, S. S. (1993) processing of ber preparation of dried ber powder and tuty-fruity. Beverage \& Food World,20 (9): 28-29.

Chevalier, A. (1947) Les jujubier on Ziziphus del'ancien monde etl'utilisation de leurs fruits [in French]. Revue Internationale de botanique appliqué etd'agriculture tropicale (Paris), 27 (301/2): 470-483.

Dalziel, J. M. (1937) The Useful Plants of West Tropical Africa. Crown Agents, London, 2nd reprint, 1955.

Devi, M. P., Bhowmick, N., Bhanusree, M. R., and Ghosh, S. K. (2015). Preparation of Value-Added Products Through Preservation. In Value Addition of Horticultural Crops: Recent Trends and Future Directions (pp. 13-41). Springer India.

Dubey, H., Parihar, P. and Kumar, S. (2014). Quality attributes of ber jam during storage. JNKVV Research Journal, 48(2): 203-206

Elevitch, C. R. (2004). The Overstory Book: Cultivating Connections with Trees. PAR.

FACT Net http://v1.winrock.org/forestry/ factnet.htm

Hailwa, J. (1998) Non-wood forest products in Namibia. Directorate of Forestry,
Ministry of environment and Tourism. In: http://www.fao.org/documents/ show_cdr.asp?url_file=/DOCREP/003 /X6694E/X6694E00.HTM

http://vikaspedia.in/agriculture/post-harvesttechnologies/technologies-for-agrihorti-crops/preparation-of-ber-candy

http://www.agmrc.org/businessdevelopment/gettingprepared/valueaddedagriculture/articles/usda-value-addedag-definition/

Hutchinson, J. and Dalziel, J. M. (1958) Flora of West Tropical Africa. Crown Agents, London.

Jakhar, M.S. and Pathak, S. (2012). Studies on the preparation and storage stability of blended ready to serve from $\mathrm{Ber}$ (Zizyphus mauritiana Lamk.) and jamun (Syzigium cumini Skeels.) pulp. Plant Archives, 12(1): 533-536.

Jawanda, J. S. and Bal, J. S. (1978). Studies on physicochemical characteristics of ber CVS grown at Ludhiana. Horticulture Journal, 1: 42.

Kadam, S. S. (2001). New products from arid and semi-arid fruits. Indian Journal of Horticulture, 58 (1\&2): 170-171.

Kadzere, I. (1998) Role of Ziziphus mauritiana in the livelihood of some communities in Zimbabwe. In International Workshop on Ziziphus mauritiana, Harare, Zimbabwe, 13-16 July, 1998.

Kaikadi, M.A., Chavan, U.D. and Adsule, R.N. (2006). Studies on preparation and shelf-life of ber candy. Haryana Journal of Horticulture Sciences, 35(3\&4): 49-50.

Kalikiti, F. (1998) Ziziphus mauritiana in Siavonga district, Zambia. In International Workshop on Ziziphus mauritiana, Harare, Zimbabwe, 13-16 July, 1998.

Khurdiya, D. S.(1980a). A new beverage from dried ber (Zizyphus mauritiana 
L). Journal of Food Science and Technology, 17: 158-159.

Khurdiya, D. S.(1980b). Studies on dehydration of ber (Zizyphus mauritiana L) fruit. Journal of Food Science and Technology,17:127-130.

Khurdiya, D.S. and Sinoh, R.N. (1975). Ber and its products. Indian Horticulture, 20: $5-25$.

Koley, T.K., Charanjit, K., Shweta, N., Shweta, W., Seema, J and Sarika. (2011). Antioxidant Activity and phenolic content in genotypes of Indian jujube (Zyziphus mauritiana Lamk.). Arabian Journal of Chemistry.

Krishna, H. and Parashar, A. 2012. Phytochemical Constituents and Antioxidant Activities of Some Indian Jujube (Ziziphus mauritiana Lamk.) Cultivars. Journal of Food Biochemistry. 1-6.

Kumar, D. and Nath, N. (2002). Development of chuhara-like product from ber by osmo-air drying process. Journal of Food Science and Technology, 39(5):484-488.

Kumar, D. and Nath, N. (2002). Development of chuhara-like product from ber by osmo-air drying process. Journal of Food Science and Technology,39(5): 484-488

Kumar, M. (2006). Studies on suitability of ber fruits for preparation of different products. Ph. D. Thesis, CCS Haryana Agricultural University, Hisar, Haryana.

Kumar, M., Singh, D., Godara, R.K., Sandooja, J.S. and Singh, S. (2007). Quality evaluation of ready to serve beverage from chemically preserved ber pulp. Haryana Journal of Horticulture Sciences, 36(3\&4): 255258.

Madan, M. and Ullasa, B.A. (1993).Post harvest losses in fruits. Advances in
Horticulture, vol. IV. (eds. Chadha, K. I. and Pareek, O. P.), Malhotra Publishing House, New Delhi, pp. 1795-1810.

Maposa, M. and Chisuro, D. (1998) Importance of Ziziphus mauritiana (masau) in the Mukumbura area of Zimbabwe - From a farmer's and extensionist's point of view. In International Workshop on Ziziphus mauritiana, Harare, Zimbabwe, 13-16 July, 1998.

Nandwani, D., and Duquesne, I. (2014). Sustainable Horticultural Systems. Springer International Publishing.

Neeraj, G. and Kaul, R. K. (2011). Preparation of Chuhara-like product from ber (Zizyphus mauritiana Lamk.) through osmo-air drying process. Applied Biological Research, 13(2): 94-98.

Oudhia, P. (2001-2003) Research Note on Medicinal herb of Chhattisgarh, India having less known traditional uses, IX. Boir (Ziziphus nummularia, family: Rhamnaceae).

Plant Botanic. Searching for the truth about herbal medicine. http://www. planetbotanic.ca/fact_sheets/jujube_fs. htm

Ranganna, S. (1977). Handbook of Analysis and Quality Control for Fruit and Vegetable Products, Jams, Jellies, Marmalade and Preserve.

Rao, J. V. S., Reddy, K. R. and Das, V. S. R. (1981). Physiological studies of some semi arid scrub species. Indian Journal of Experimental Biology, 19(3): 256-260.

Shobha, D. and Bharathi, P (2007). Value Addition to Ber (Zyziphus mauritiana Lamk.) Through Preparation of Pickle. Karnataka Journal of Agriculture Sciences, 20(2): 353-355

Singh, K.K. (1964). The ber in India. Fill. Bull. ICAR. New Delhi. 17: 31. 
Singh, L., Lal, G. and Singh, S.(1944). Candying of bers (Zizyphus jujuba) and orange peel. Punjab Fruit Journal, 8: 29-30.

Srivastava, R. P. and Kumar, S.(2002). Fruits and vegetable Preservation: Principles and Practices. International Book Distributing company, Lucknow.

Sucharitha, K. V., Beulah, A. M. and Sathiya, C. (2012). Development and standardization of ber-pineapple jam. International Journal of Food, Agriculture and Veterinary Sciences, 2(3): 126-130.

Take, A. M., and Bhotmange, M. G. (2012). Preparation of candy from ber-a value addition. Food Science Research Journal, 3(2), 217-220.

Tanmay, K.K., Shweta, W., Prerna, N., Awasthi, O.P. and Charanjit, K. (2011). Nutraceutical composition of
Zizyphus mauritiana Lamk (Indian ber): Effect of enzyme-assisted processing. International Journal of Food Sciences and Nutrition, 62(3): 276-279.

Williams, T. O. (1998) Multiple uses of common pool resources in semi-arid West Africa: A survey of existing practices and options for sustainable resource management. http://www. odi.org.uk/nrp/38.html

Younis, K., Siddiqui, S., Jahan, K. and Dar, M. S.(2014). Production of wine from over ripe guava (Psidium guajava $\mathrm{L}$ Cv. Safada) and ber (Ziziphus mauritiana L Cv. Umran) fruits using Saccharomyces cerevisiae Var. HAU 1. Journal of Environmental Science, Toxicology and Food Technology, 8(1):93-96.

\section{How to cite this article:}

Nidhi Dalal, Neeraj and Vinita Bisht. 2019. Value Added Products from Ber. Int.J.Curr.Microbiol.App.Sci. 8(01): 1603-1615. doi: https://doi.org/10.20546/ijcmas.2019.801.169 